\title{
Investigating in the J-Curve Phenomenon in Tunisia- ARDL Bound Test Approach
}

\author{
Elham Shubaita ${ }^{1}$, Muhammad Mar'i2 \& Mehdi Seraj ${ }^{3}$ \\ ${ }^{1}$ Department of Economic Policy Management, An-Najah National University, Palestine \\ 2Department of Banking and Finance, Near East University, North Cyprus, Mersin, Turkey \\ ${ }^{3}$ Department of Economic, Near East University, Nicosia, North Cyprus, Turkey \\ elham.shbaita0@gmail.com,muhmd.marai@gmail.com,mehdi.seraj@neu.edu.tr
}

\begin{abstract}
This paper investigates the relationship between trade balance, real exchange rates, and incomes in Tunisia by adopting the autoregressive distributed model (ARDL) by using data over the period of 1980 to 2018. We also used the bound test cointegration between variables at a $10 \%$ significant level. Our findings show that the Tunisia economy does not match the Marshall-Lerner condition in the long run, that provides an accurate description of the particular situation for which a country currency devaluation or depreciation its currency under both fixed or floating regime is predicted to enhance the trade balance of a country, which means there is no j-curve phenomenon in the long run, which tries to differentiate between the change of short-run and long-run effects in the change of exchange rate on the trade balance. Our findings match the Marshall-Lerner condition in the short run and can confirm the existing j-curve in the case of Tunisia.
\end{abstract}

Keywords: ARDL model, Exchange Rate, Income, J-curve, Trade Balance.

\section{Introduction}

Tunisia was considered a blueprint of productive growth until the early 1980s, with a per capita income of $\$ 1,300$ in 1980 (Ghose, Jamal, \& Radwan, 2005, P1). But by mid of the 1980S, the economic crises start to strike the country till now. As a developing country, Tunisia has many challenges that have to overcome and develops appropriate strategies to meet these challenges in the future, these challenges include political issue, instability increased rate of unemployment, poverty and income inequality (Achy, 2011; Ghose et al., 2005). Policymakers try to control financial and economic crises that hit Tunisia by making new regulations to help enhance the economy, increase trade openness, and economic growth (Jedidia et al., 2014). The recent data which are coming to Central Bank of Tunisia data show that there is a kind of deficit in the balance of external payments in recent years, as it rose to the limits of $11.2 \%$ of the gross domestic product during the year 2018, as a result of the country's political fluctuations and social pests represented In large numbers of unemployment, in addition to the decline in the volume of exports, as Tunisia lost foreign markets because it did not fulfill its pledges to export phosphates, oil, and oil as a result of the low investment activity in exploration for oil and natural gas which negatively affected the net assets of foreign currency (Braham, 2018). The trade balance has got the attention of policymakers due to its importance in the economy that's the surplus trade balance enhances the economy, where the export is considered as one of determining economic growth (Keho, 2015).

Both of the exchange rate and trade balance is considered a significant element of macroeconomic measures whose change can affect a country's economy positively or negatively (Necșulescu \& Șerbănescu, 2013). The "competitive devaluation" whereby a country trading position can be improved by devaluing its currency has long take policymakers' concern. Throughout the Gold Standard of fixed exchange rates before the 1st World War, this idea was highly attractive, till now some countries could see currency devaluation as a benefit to their export markets. The condition "Marshall-Lerner" (M-L), named after Marshall and Lerner, this theory provides an accurate description of the particular situation for which a country currency devaluation or depreciation its currency under both fixed or floating regime is predicted to enhance the trade balance of a country (Bahmani et al., 2013). This study investigates in the relationship between exchange rate and trade balance and investigates in existing J-carve phenomenon in case of Tunisia by adopting an autoregressive distributed lag model (ARDL) also the study applied impulse response analysis to catch how the series reaction when a shock hitting the system and Variance Decomposition to show effect variance of the forecast error by employing vector autoregressive (VAR). Through this research, which focuses on Tunisian balance of payments, it is possible to come up with ideas for reforming monetary policy and attention to support the balance of services and thus reduce the impact of the trade balance deficit in Tunisia. The theory of elasticity states that the influence on trade balance of devaluation relies on elasticity of imports and exports. 
The supporters of this theory claim that the change in the short-term in the exchange rate can be driven by transaction that could cause a drop in the trade balance. In the long run, exports and import quantities are adjusted in an increase in their elasticities and thereby trigger a quantity change. As quantity changes, the price of the country's export's product will decrease for the country which minimizes its currency but the price of goods which imported increase and hence lowers its demand (Eke et al., 2015). The theoretical model on which trade elasticity is estimated is an imperfect substitute model, the model supposes that exports and imports are incomplete substitutes for locally manufactured goods (Crane et al., 2007). The "Marshall \& Lerner" (M\&L) condition gives an accurate description of the circumstances in which a currency devaluation or depreciation is supposed to improve the trade balance of a country, briefly, a country's trade balance is the value of the country exports minus the value of the country imports, so the currency's country devalued leads the price to decrease and therefore the exports quantity should increase and the imports quantity decrease. But the trade balance enhancement cannot be done unless the quantity of export or quantities of import quantities react adequately to substitute the damage in price.

Thus, to meet Marshall-Lerner (LM) condition the total elasticities of imports and export demand price (in absolute value) have to be more than one (Aghevli et al., 1991; Bahmani et al., 2013; Cooper, 1992; Edwards, 1989). Therefore authority unwilling to decrease their currency in many countries to trade balance's improvement (Kyophilavong et al., 2013). The J-curve Phenomenon introduced by Magee, (1973), which tries to differentiate between the change of short-run and long-run effects in the change of exchange rate on the trade balance and it is based on an analysis of the dynamic effect of the exchange rate change on the trade balance, which appears when the Marshall condition is met, which states that if the sum of foreign and domestic elasticities of demand in their absolute value is greater than 1, the devaluation is likely to follow a decline in the trade balance then progress in the trade balance (Bahmani-Oskooee \& Saha, 2017). The J-curve theorem suggests that the export goods should become cheaper for customers abroad after the decline of the currency of the country. Furthermore, other country products will also turn into an expensive product to import to local customers. Therefore, under this theory, the export of the country should be greater and less imported with a long-run depreciated local currency (Ongan et al., 2018).

Most of the studies that have assessed the relationship between exchange rate and trade balance have found different and not consistent findings of the effect of the exchange rate on the trade balance in the long-run and short-run. In this section, here, briefly review some studies about changes in the exchange rate and trade balance. Using the bilateral trade flows of about two-thirds of world trade in 33 countries Yazgan \& Ozturk, (2019) have to reinvestigate the relationship among each of trade flows, incomes, and real effective exchange rates, the study used quarterly data overall the first quarter of 1981to second quarter of 2010 and reveals that the actual devaluation of the local currency in most countries has long-term positive consequences on the home country's trade balance. This long-term influence is expressed for a limited number of countries in the short term. Onakoya et al. (2019), investigate the effect of "J-curve" in Nigeria which is the relationship between trade balance and real effective exchange rate from 1980-2016, and showed empirical evidence that the relationship hasn't proved in long-run while the trade balance in the short-run benefit from devaluation. Suwanhirunkul \& Masih, (2018), applied a novel approach (NARDL) in Thailand, and they confirmed existing long-run relationship among exchange rate and trade balance and find that the depreciation improves.

Trade balance for the whole country, but due to demand elasticity of export and import has mixed results for a different sector. The study denotes that there in the short-run and long-run a tradeoff between the exporting sector and importing sector. Hunegnaw \& Kim, (2017) employed the ARDL model to examine the impact of exchange rate on trade balance for ten east African country over the period 1970 to 2013, the study's analysis showed that in long-run the depreciation affected positively on the trade balance for fourcountry, while there is no significant relationship in the short-run Arize et al. (2017). By using nonlinear autoregressive distributed lag model (NARDL) for eight countries, the study investigates in the effect of real effective exchange rate on the trade balance, the paper indicates that exchange rate has an impact on trade when there a separation between depreciation and appreciation. The study indicates that in the long-run the reaction of the trade balance to depression more strongly than to appreciation. Fariditavana, (2016), Examine whether the influence of depreciation and appreciation of exchange rate on the trade balance is different, the study shows by using data for thirteen advanced and not advanced country that the effect is asymmetric in both to react to the real exchange rate's changes. 
Concerning one trade partner a country's trade balance could improve while it could deteriorate to another trade, partner. Trinh, (2014), Investigates the short-run and long-run effect of exchange rate on the trade balance in Vietnam using the autoregressive distributed lag model the result shows that in the short-run and long-run the real exchange rate affects positively on the trade balance, thus including that an enhancement in the trade balance can be led by currency depression. More precisely, currency appreciation can contribute to trade balance breakdown. Moreover, the study result showed that the currency of vitamin is effectively pegged to the US dollar. It's clear that there are many ways to measure the influence of the exchange rate on trade balance either by employ trade statistic volume or by utilizing bilateral trade balance, previous studies had used a different model to conduct its studies. The findings of various earlier econometric studies support are different and sometimes contradictory, where Suwanhirunkul \& Masih, (2018), Hunegnaw \& Kim, (2017), Fariditavana, (2016), Trinh, (2014) indicates that there significant relationship on both long-run and shortrun. Yazgan \& Ozturk, (2019), Onakoya et al. (2019), Hunegnaw \& Kim, (2017), suggest a lack or limited evidence for J-curve relationship term on short-run or long-run. This paper is structured as follows. Sections two provide empirical models and data, section three discusses the study's results, and section four shows our research conclusions.

\section{Methodology}

Based on the previous discussion and to investigate in the existing j-curve phenomenon in case of Tunisia the study used trade balance as the dependent variable and effective exchange rate, Tunisia income, world income as the explanatory variable, the empirical equation is modeled as follows:

$T B_{t}=\alpha_{1}+\alpha_{2} E F+\alpha_{3} T U+\alpha_{4} W I+\mu_{t}$

Where $\mathrm{TB}_{\mathrm{t}}$ represents trade balance (log exports minus log imports), EF represents log effective interest rate, TU is the log real gross domestic product (GDP), and WI is representing world income. Log US GDP used as a proxy, all data series used in natural logarithms, the study uses annual observation for the period of 1980 to 2018. The data sources are from the World Bank. Plot. 1 shows the variables plot. The study employ econometrics technic to analyze the model and get better understanding about j-curve phenomenon, we employ unit root test to check stationary of the variable and breakpoint test to avoid biased in acceptance of unit root test and ensure robustness of series (SHARMA et al., 2019). Then we adopt ARDL model based on unit root test result to test the relationship between the study's variables. Last we use impulse response to test short-term dynamic interactions between the variables (Lütkepohl, 1991).

\section{Plot 1: Variable of Study}

$T B$
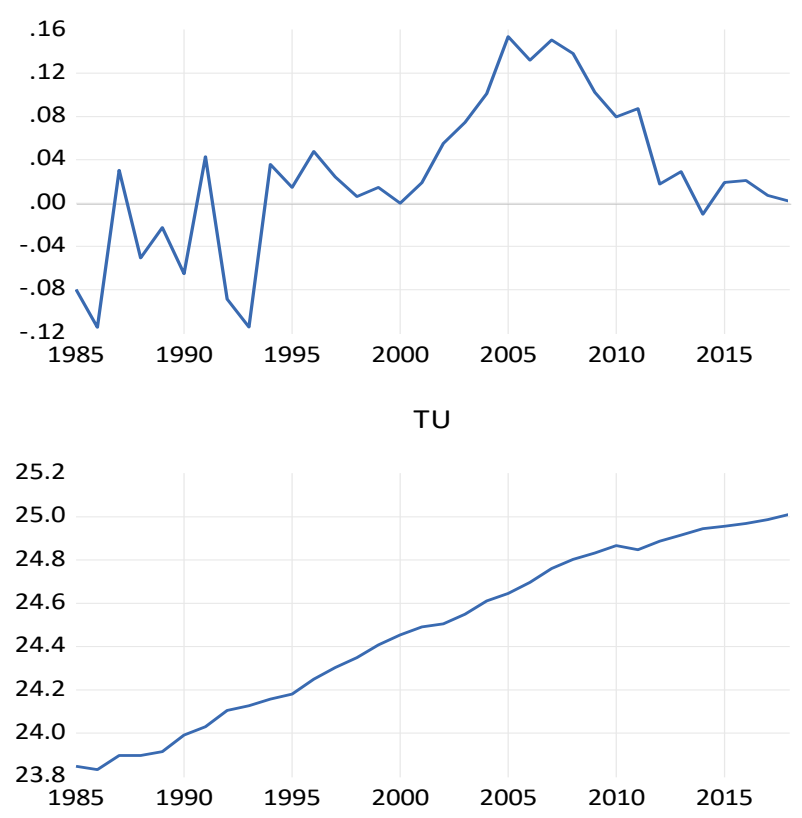

EF
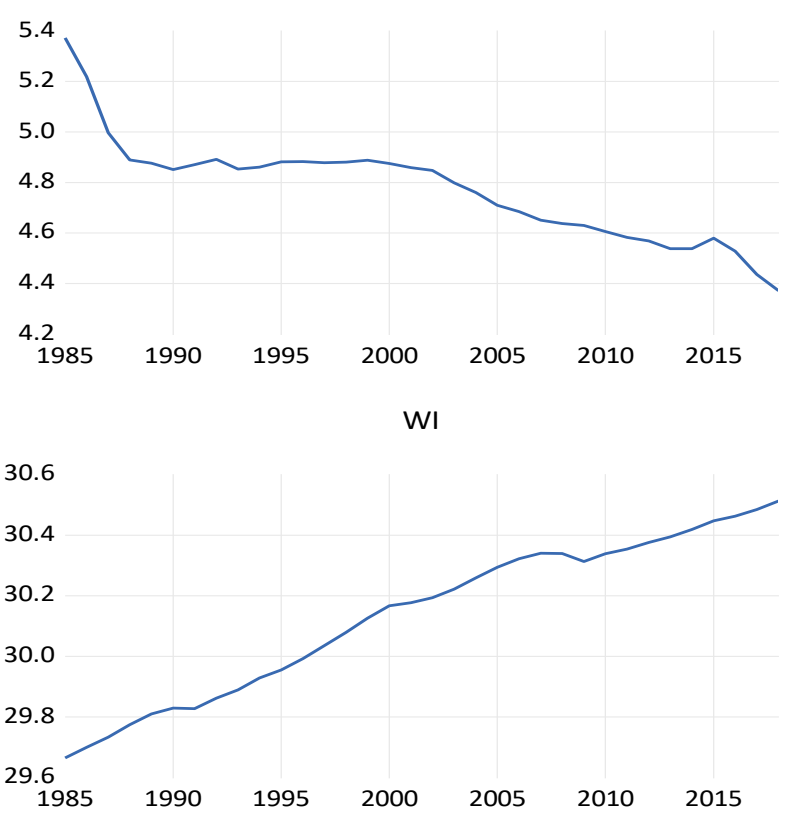
Unit Root Test: Usually before starting analysis of cointegration the study check variable stationary, testing stationary for classical regression is important to get a valid result, where applying the analysis without testing the stationary may produce an incorrect result. Performing regression on such nonstationary tend to show high R2 as a result of spurious regression generated from using nonstationary series in the regression. The study tests the stationary of the variables using the most popular test which are Augmented DickeyFuller test (ADF), Phillips Perron (PP) test. The Augmented Dickey-Fuller test has the following model:

$y_{t-1}=\psi y_{t-1}+\sum_{i=1}^{n} \alpha_{i} \Delta y_{t-1}+u_{t}$

Where, $y_{t-1}=y_{t-1}-y_{t-2}$, $\mathrm{n}$ refers to lags number, $\psi$ is a parameter of $y_{t-1}$ and it represents the drift, $u_{t}$ is white noise. The null hypothesis of the test is existence of unit root, the alternative hypothesis is there's no unit root. Both (ADF) and (PP) produce an identical result (Brooks, 2019), but the last handle the serial correlation without adding lagged difference through using non-parametrical analysis, the Phillips Perron (PP) test is performed as follows: $\Delta Y_{t}=\alpha+\theta t+\lambda Y_{t-1}+u_{t}$

The null hypothesis is the series is not stationary, that is $\lambda=0$, the alternative hypothesis that the series $Y$ is stationary (Beik \& Wardhana, 2011).

ARDL Bound Test: The study used the ARDL bounds in testing the relationship between the study's variables; this approach developed by Pesaran et al. (2001), this approach has become common as it crushes the conventional cointegration test that required the study's variable to be integrated with the same order and non-stationary. This approach has many advantages comparing to other cointegration techniques, these advantages including that the order of integration of the variables are varied or unknown (Sam et al., 2019), also this approach assess simultaneously the effects of a particular variable on the other in both short-run and long-run in addition to detach effects of each short run and long run (Bentzen \& Engsted, 2001). To carry out the bounds testing cointegration the study employs standard log-log functional specification as follow:

$\Delta \ln T B_{t}=\alpha_{0}+\sum_{i=1}^{\rho} c_{i} \Delta \ln T B_{t-i}+\sum_{i=1}^{\rho} d_{i} \Delta \ln E F_{t-i}+\sum_{i=1}^{\rho} e_{i} \Delta \ln T U_{t-i}+\sum_{i=1}^{\rho} f_{i} \Delta \ln W I_{t-i}+\pi_{1} \ln T B_{t-1}+$ $\pi_{1} \ln E F_{t-1}+\pi_{1} \ln T U_{t-1}+\pi_{1} \ln W I_{t-1}+v_{i t}$

Where $\Delta$ represents the first different operator, the drift component represented by $\alpha_{0}, t$ denotes to time trend and $v_{i t}$ is the error term and has to be white noise. The maximum lag length selected by the Akaike Information Criterion (AIC) and represented by $\rho$. The ARDL bound test conduct by estimating F-statistics and comparing its value with two critical values (upper bound and lower bound). The absence of long relationship denoted by the null hypothesis for $\left(F_{T B}(T B / E F, T U, W I)\right)$ is $\left(\mathrm{H}_{0}: \pi_{1}=\pi_{2}=\pi_{3}=\pi_{4}=0\right)$ against $\left(\mathrm{H}_{1}: \pi_{1} \neq \pi_{2} \neq \pi_{3} \neq \pi_{4} \neq 0\right)$. The null hypothesis of no cointegration will be rejected if the F-statistic has a value greater than the upper bound if F-statistic value lower than the lower limit then we accept the alternative hypothesis of no cointegration, but the decision is rendered inconclusive if the value of F-statistic lie between upper and lower limit (Kyophilavong et al., 2013). To assess the short-run parameters using the error correction model (ECM), the sign of the lagged error correction term (ECMt - 1) coefficient has to lie between 0 and 1 and must be negative and also statistically significant (Tursoy, 2019).

Impulse Response: ARDL cointegration is followed by an impulse response analysis to examine the dynamics of the financial time series. The impulse response is used as a tool for analyzing short-term dynamic interactions between the variables and has an advantage for its ability to measure how a standard deviation shock to a component in the system is transferred over time to other variables. The zero value of impulse response indicates the absence of the dynamic causality between the variable (Lütkepohl, 1991).

\section{Results and Discussion}

Normally we star analysis by conducting unit root test, in case of using ARDL model we conduct unit root test to avoid the spurious result in F-test that occur when the variable is stationary at I(2) (Ouattara, 2004). Table 1 shows the Perron, (1988) unit root test. It shows that the trade balance and effective interest rate I(0) Without Constant \& Trend while other variables are integrated at the first difference I(1). 
Table 1: Phillips-Perron (1988) Unit Root Test

\begin{tabular}{llllll}
\hline & & TB & EF & TU & WI \\
\hline With Constant-I(0) & t-Statistic & -2.27 & -1.00 & -1.21 & -1.72 \\
With Constant-I(1) & t-Statistic & $-9.84^{* * *}$ & $-2.81^{*}$ & $-6.45^{* * *}$ & $-4.07^{* * *}$ \\
With Constant \& Trend -I(0) & t-Statistic & -2.72 & -1.89 & -0.657 & -1.01 \\
With Constant \& Trend-I(1) & t-Statistic & $-9.92^{* * *}$ & -2.75 & $-6.56^{* * *}$ & $-4.13^{* *}$ \\
Without Constant \& Trend -I(0) & t-Statistic & $-2.28^{* *}$ & $-2.78^{* * *}$ & 9.47 & 7.90 \\
Without Constant \& Trend -I(1) & t-Statistic & $-9.95^{* * *}$ & $-2.51^{* *}$ & $-2.61^{* *}$ & $-1.75^{*}$
\end{tabular}

Note: ${ }^{*}$ Denote significant level at $10 \%,{ }^{* *}$ at $5 \%$ and ${ }^{* * *}$ at $1 \%$.

'The conventional unit root tests are biased towards a false acceptance of stationarity when the data exhibits trend stationarity with a structural break. Therefore, researchers estimated structural breaks to ensure the robustness of the series' (SHARMA et al., 2019, p 53). The study has employed Quandt-Andrews Breakpoint Test as show Table 2 there is a breakpoint in 2005, for this, the study used dummy variable in 2005.

Table 2: Quandt-Andrews Breakpoint Test

\begin{tabular}{lll}
\hline F-Statistic & Value & Break Date \\
\hline LR & $11.96^{* * *}$ & 2005 \\
Wald & $35.90^{* * *}$ & 2005 \\
\hline
\end{tabular}

Note: ${ }^{* * *}$ Indicates a significant level of $1 \%$.

The optimal lag length was selected based on the Akaike Information Criterion (AIC), Table 3 shows the ARDL cointegration test. By comparison of F-statistic (3.65) with a critical value of upper bound (3.454) at a significant level $10 \%$, can reject the null hypothesis of no cointegration and conclude that there long-run cointegration between variables at significant level $10 \%$ as reported in Table 3 .

Table 3: Result of Bound Test

F-Statistic: 3.652293, K:3

sig. level at $10 \%$ for finite Sample: $\mathrm{n}=40$

upper bound

3.454

lower bound

2.592

R-squared

0.81

Adj $\boldsymbol{R}^{2}$

0.72

The coefficient of the ARDL model in the long run and short run are reported in Table 4. The result indicates that in the long run that real income has a negative relationship with trade balance but insignificant. The relationship between trade balance and the effective exchange rate is positive but insignificant, also positive with world income but significant. The result of the long-run model as shown indicates that the Marshall Lerner condition does not exist in Tunisia in the long-run. These results are consistent with a study by Onakoya et al. (2019) and Duasa, (2007) who found that there is no relationship in the long run.

Table 4: Long-Run and Short-Run Coefficient

\begin{tabular}{lll}
\hline Variable & Coefficient & t-Statistic \\
\hline Long-run results & & \\
EF & 0.306725 & 1.143 \\
TU & -1.233408 & -1.638 \\
WI & 2.046655 & $1.830^{*}$ \\
C & -32.78677 & $-1.960^{*}$ \\
Short-run results & & \\
\hline
\end{tabular}




\begin{tabular}{lll} 
& $\begin{array}{c}\text { Journal of Economics and Behavioral Studies (ISSN: 2220-6140) } \\
\text { Vol. 12, No. 5, pp. 23-32, October 2020 }\end{array}$ \\
\hline \hline & & \\
\hline D(TB (-1)) & -0.317601 & $-2.751^{* *}$ \\
D(EF) & 0.333684 & 1.709 \\
D(EF(-1)) & -0.616320 & $-2.690^{* *}$ \\
D(EF(-2)) & 0.513451 & $2.746^{* *}$ \\
D(TU) & -0.257547 & -0.888 \\
D(TU(-1)) & -0.433536 & $-1.745^{*}$ \\
D(WI) & -1.038886 & $-2.404^{* *}$ \\
DU05 & 0.092373 & $2.203^{* *}$ \\
CointEq(-1) & -0.397127 & $-4.630^{* * *}$ \\
\hline
\end{tabular}

Note: ${ }^{*}$ Denote significant level at $10 \%,{ }^{* *}$ at $5 \%$ and ${ }^{* * *}$ at $1 \%$.

The result also shows that the speed of adjustment (-0.397127) is negative and statistically significant at $1 \%$, which implies that variation in the short-run is corrected by -0.40 in the long run. In the short run, the lagged one year of the real income and world income has a significant and negative relationship with trade balance. The result also shows that the one year lag of effective exchange run indicate that the trade balance will be destroyed by a devaluation of local currency since it has a negative and statistically significant impact trade balance in the short run, anyway two years lagged of the effective exchange rate has a statistically positive significant impact also the dummy variable significant at 5\%, the world economy has a negative significant impact at significant level 5\%. The short-run result confirms of existing of the J-curve phenomenon in case of Tunisia. The result of the short-run consistent with Trinh, (2014) for Vietnam regarding the short run and consistent with Onakoya et al. (2019) for Nigeria regarding exiting of J-curve phenomenon in short-run and absence this phenomenon in long run. There are many additional diagnostic tests suggested by B. Pesaran \& Pesaran, (2010) including serial correlation tests, function form, normality, and heteroscedasticity, also they suggest conducting cumulative sum (CUSUM) and cumulative sum of squares (CUSUMSQ) tests based on the recursive regression residuals. The study applied diagnosis tests to fill the specification of the model suggested by B. Pesaran \& Pesaran, (2010) which mentioned before. Table 5, shows diagnosis test, the result confirms adequacy of the model.

Table 5: Diagnosis Test

\begin{tabular}{llc}
\hline & F-Statistic & Obs* $^{*} \boldsymbol{R}^{\mathbf{2}}$ \\
\hline Serial correlation test & 0.667285 & 2.151129 \\
& $\mathrm{P}, \mathrm{F}(2,21)=0.5236$ & $\mathbf{P}\left(\chi^{2}\right)=0.3411$ \\
Heteroskedasticity Test & 1.158268 & 13.56050 \\
& $\mathrm{P}, \mathrm{F}(12,23)=0.3659$ & $\mathbf{P}\left(\chi^{2}\right)=0.3296$ \\
Ramsey RESET Test & 0.768075 & 1.235407 \\
& $\mathrm{P}, \mathrm{F}(1,22)=0.3903$ & $\mathbf{P}\left(\chi^{2}\right)=0.2624$ \\
& & \\
Test of normality & Jarque-bera $=1.257$ & $\mathrm{P}=0.533$ \\
\hline
\end{tabular}

To assess stability and constancy of the model parameter, the cumulative sum of recursive residuals (CUSUM) and cumulative sum of recursive residuals squared tests (CUSUMSQ) which develop by Brown et al. (1975) has been used. Plot 2 represents CUSUM and CUSUMSQ. 

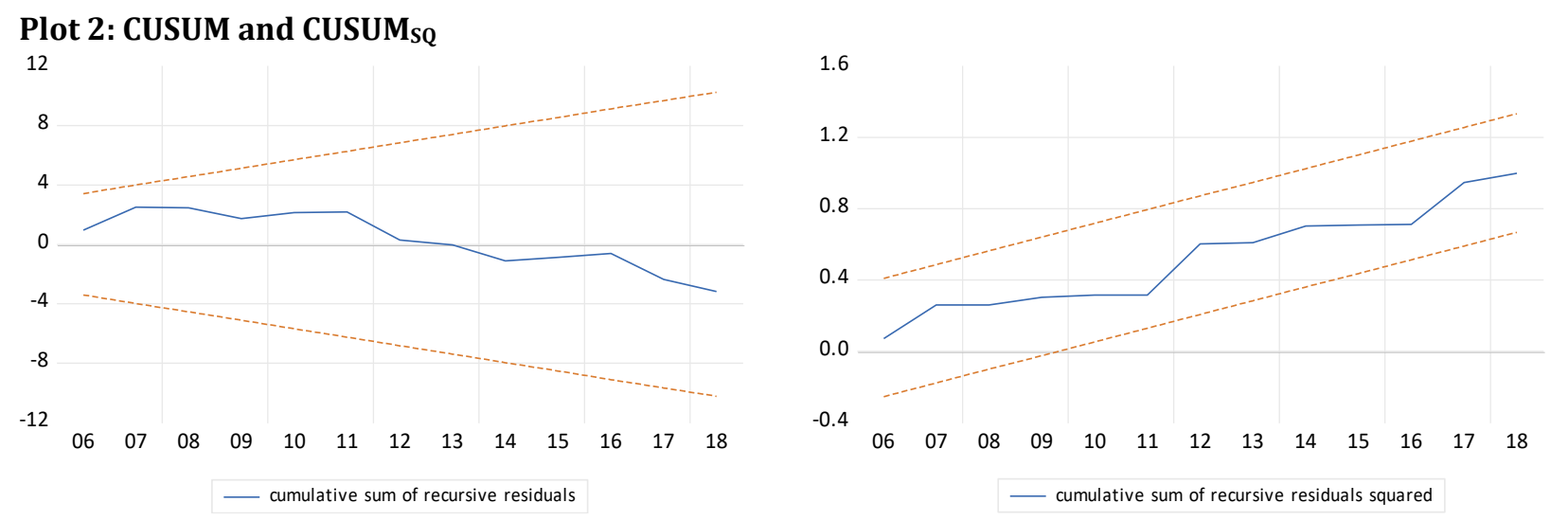

The area within Orange dashed lines indicates a significant area at $5 \%$ plot 2 . This indicates that CUSUM and CUSUM $_{S Q}$ plots locate within critical bounds which mean that the study parameter is stability and constancy over the sample period. Variance Decomposition result reported in Table 6. It shows that the trade balance till 10th period explained by each of effective exchange rate, Tunisia income and world income of $6.188 \%$, $1.362 \%$, and $40.966 \%$ respectively, the other $51.484 \%$ clarified by its self-innovations. The trade balance, Tunisia income, and world income explain $12.381 \%, 3.967 \%$, and $3.107 \%$ respectively of the effective exchange rate. The trade balance, effective exchange rate has a negligible portion of explanation Tunisia income while the world income explains $53.320 \%$ of Tunisian income shocks. The trade balance, effective exchange rate, and Tunisia income explain 9.847\%, 1.093\%, 19.132\% respectively of world income shocks. The world income the most variable contributes to the explanation of trade balance while the other variables have a negligible portion. The percent of explaining shocks in trade balance by effective exchange rate increasing over time, while the percent of explaining shocks by its innovations decreasing which is consistent with study result.

Table 6: Variance Decomposition

\begin{tabular}{|c|c|c|c|c|c|c|c|c|c|}
\hline $\begin{array}{l}\text { Period } \\
\text { TB }_{\mathrm{t}} \text { : }\end{array}$ & $\mathrm{TB}_{\mathrm{t}}$ & $\mathbf{E F}_{\mathrm{t}}$ & $T U_{t}$ & $\mathbf{W I}_{\mathrm{t}}$ & $\begin{array}{c}\text { Period } \\
\text { TU }_{t}\end{array}$ & $\mathrm{~TB}_{\mathrm{t}}$ & $\mathbf{E F}_{\mathrm{t}}$ & $\mathbf{T U}_{\mathrm{t}}$ & $W I_{t}$ \\
\hline 1 & 100.000 & 0.000 & 0.000 & 0.000 & 1 & 0.010 & 0.816 & 99.174 & 0.000 \\
\hline 2 & 93.501 & 1.053 & 0.825 & 4.621 & 2 & 0.228 & 7.050 & 90.849 & 1.873 \\
\hline 3 & 84.078 & 0.864 & 0.839 & 14.219 & 3 & 1.386 & 10.304 & 81.686 & 6.625 \\
\hline 4 & 72.171 & 0.826 & 0.800 & 26.202 & 4 & 1.204 & 10.805 & 73.619 & 14.372 \\
\hline 5 & 62.743 & 1.546 & 0.702 & 35.010 & 5 & 1.201 & 9.755 & 65.701 & 23.342 \\
\hline 6 & 57.012 & 2.662 & 0.691 & 39.635 & 6 & 0.957 & 8.252 & 58.313 & 32.477 \\
\hline 7 & 53.729 & 4.039 & 0.820 & 41.412 & 7 & 0.881 & 6.886 & 51.848 & 40.385 \\
\hline 8 & 52.286 & 5.149 & 1.004 & 41.561 & 8 & 1.205 & 5.798 & 46.523 & 46.474 \\
\hline 9 & 51.668 & 5.876 & 1.203 & 41.253 & 9 & 1.804 & 5.007 & 42.495 & 50.695 \\
\hline 10 & 51.484 & 6.188 & 1.362 & 40.966 & 10 & 2.606 & 4.459 & 39.614 & 53.320 \\
\hline$E F_{t}$ & & & & & $W I_{t}$ & & & & \\
\hline 1 & 0.008 & 99.992 & 0.000 & 0.000 & 1 & 0.196 & 1.506 & 18.572 & 79.727 \\
\hline 2 & 0.110 & 98.965 & 0.895 & 0.030 & 2 & 1.125 & 1.093 & 13.749 & 84.033 \\
\hline 3 & 1.101 & 97.579 & 0.960 & 0.360 & 3 & 2.480 & 0.808 & 12.989 & 83.723 \\
\hline 4 & 3.134 & 94.915 & 0.842 & 1.108 & 4 & 4.413 & 0.699 & 12.927 & 81.961 \\
\hline 5 & 5.969 & 91.217 & 0.755 & 2.059 & 5 & 6.140 & 0.715 & 13.503 & 79.642 \\
\hline 6 & 8.896 & 87.333 & 0.949 & 2.822 & 6 & 7.639 & 0.810 & 14.410 & 77.140 \\
\hline 7 & 11.082 & 84.235 & 1.518 & 3.165 & 7 & 8.696 & 0.936 & 15.545 & 74.823 \\
\hline
\end{tabular}


Journal of Economics and Behavioral Studies (ISSN: 2220-6140)

Vol. 12, No. 5, pp. 23-32, October 2020

\begin{tabular}{llllllllll}
\hline $\mathbf{8}$ & 12.194 & 82.278 & 2.344 & 3.185 & 8 & 9.376 & 1.038 & 16.771 & 72.816 \\
$\mathbf{9}$ & 12.469 & 81.195 & 3.216 & 3.120 & 9 & 9.732 & 1.090 & 17.993 & 71.185 \\
$\mathbf{1 0}$ & 12.381 & 80.545 & 3.967 & 3.107 & 10 & 9.874 & 1.093 & 19.132 & 69.900 \\
\hline
\end{tabular}

Plot 3 shows the impulse response of the variable. It's clear that the trade balance has a negative shock due to an effective exchange rate at less than -.02 S.D and after that positive response, this confirms the result of the existing J-curve phenomenon in Tunisia in the short run, and similar to results of variance decomposition. Almost the same response to local income while it has a positive response to world income and increasing till about .021 S.D and then start decreasing. Regarding the effective exchange rate, it has a positive response to trade balance, positive and negative response to shocks in Tunisia income, and negative response to the world economy. Tunisia income has a positive response to the effective exchange rate and world economy and a positive and negative response to the trade balance. The world income has a negative response trade balance and positive response to effective exchange rate and Tunisia income.

\section{Plot 3: Impulse Response}

Response of TB to EF
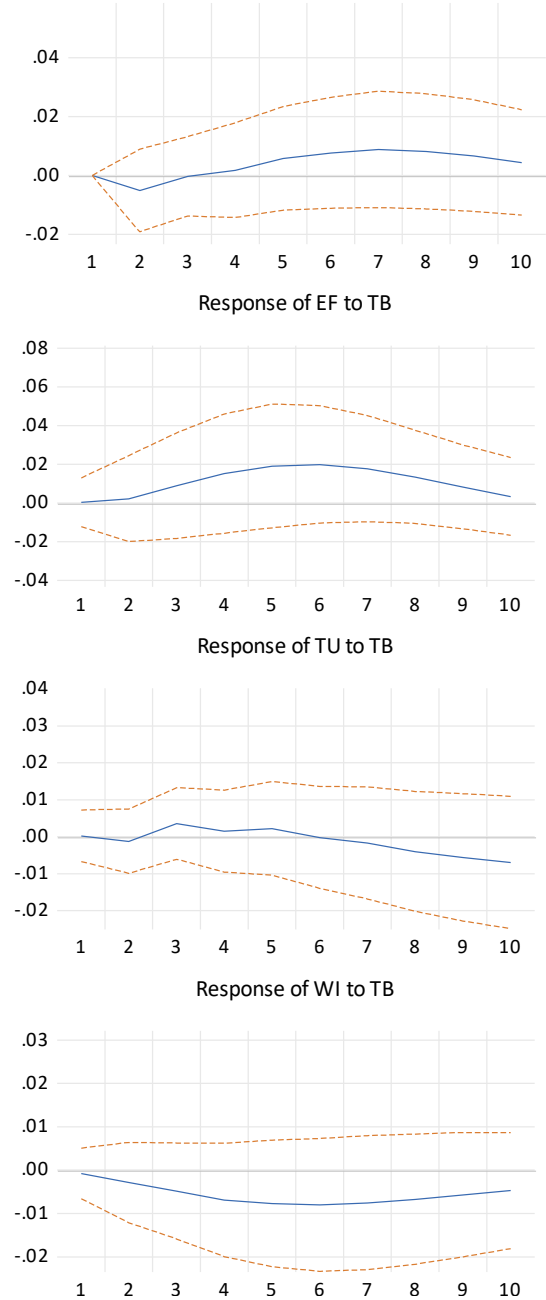

Response of TB to TU
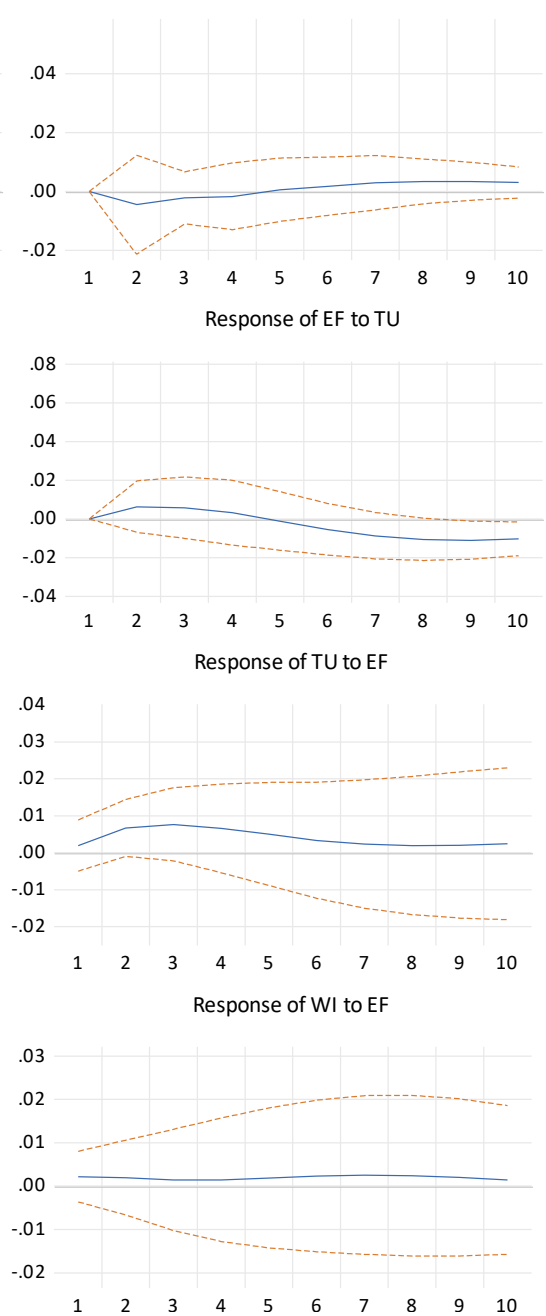

Response of TB to WI
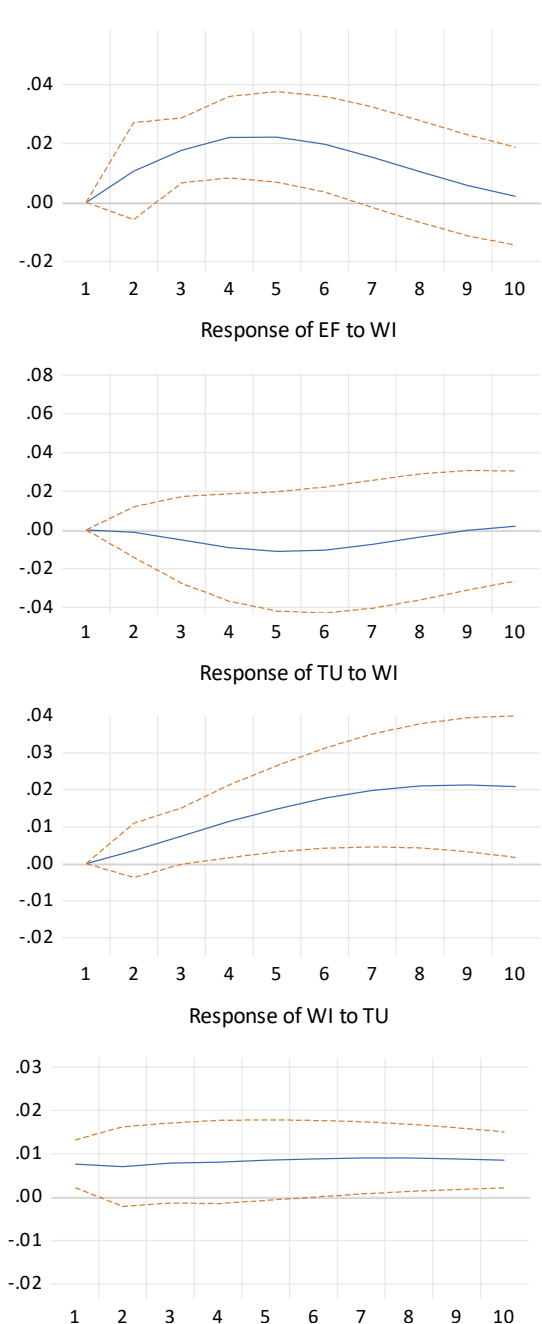

Response to Cholesky 1 S.D. (d.f. adjusted) Innovations \pm 2 S.E. 


\section{Conclusion}

This study examines the relationship between trade balance and exchange rate over the period 1980-2018 in Tunisia, and test for existing $\mathrm{j}$-curve phenomenon in case of Tunisia, the study employs econometrics technic which includes unit root test, breakpoint test, ARDL model, Variance decomposition and impulse response. The main study finding confirms existing of long run cointegration by using bound test. The coefficient of Variable is not all significant in long run. The exchange rate is not significant in long run so there's no relationship in long run which indicates that there is no J-Curve in case of Tunisia in long run. This result goes in the line with Duasa, (2007) and Onakoya et al. (2019). The relationship between study variables and trade balance is significant in short run. The relationship between trade balance and exchange rate in the short run have both positive and negative statistically significant at lag one and two respectively, the result confirms of existing of the J-curve phenomenon in case of Tunisia, and consistent with study of Fariditavana, (2016); Hunegnaw \& Kim, (2017); Suwanhirunkul \& Masih, (2018) and Trinh, (2014) the result shows that devaluation of Tunisia currency will enhance the trade balance in short run, which matches Marshall-Lerner condition. The depreciation of Tunisia Currency enhances the trade balance thus, the policies aimed at improving trade balance in short term should focus on evaluating the currency in the short-run this leads to improving the export side. The exchange rate still most important tools by the policymaker, use of exchange rate to deal with the economic issue should be done by a balance between long-run and short-run effect.

\section{References}

Achy, L. (2011). Tunisia's Economic challenges (Vol. 2011). Carnegie Endowment for International Peace Washington, DC.

Aghevli, B. B., Khan, M. S. \& Montiel, P. (1991). Exchange rate policy in developing countries: some analytical issues (Vol. 78). International monetary fund.

Arize, A. C., Malindretos, J. \& Igwe, E. U. (2017). Do exchange rate changes improve the trade balance: An asymmetric nonlinear cointegration approach. International Review of Economics \& Finance, 49, 313326.

Bahmani-Oskooee, M. \& Saha, S. (2017). Asymmetric response of the US-India trade balance to exchange rate changes: Evidence from 68 industries. The World Economy, 40(10), 2226-2254.

Bahmani, M., Harvey, H. \& Hegerty, S. W. (2013). Empirical tests of the Marshall-Lerner condition: a literature review. Journal of Economic Studies, 40(3), 411-443.

Beik, I. S. \& Wardhana, W. (2011). The relationship between Jakarta Islamic Index and other selected markets: evidence from impulse response function. Jurnal Ekonomi Dan Bisnis Airlangga (JEBA)/ Journal of Economics and Business Airlangga, 21(2).

Bentzen, J. \& Engsted, T. (2001). A revival of the autoregressive distributed lag model in estimating energy demand relationships. Energy, 26(1), 45-55.

Braham, G. (2018). The Tunisian Revolution: Another case of state failure?

Brooks, C. (2019). Introductory econometrics for finance. Cambridge university press.

Brown, R. L., Durbin, J. \& Evans, J. M. (1975). Techniques for testing the constancy of regression relationships over time. Journal of the Royal Statistical Society: Series B (Methodological), 37(2), 149-163.

Cooper, R. N. (1992). Currency devaluation in developing countries. In International Economic Policies and their Theoretical Foundations, 742-770.

Crane, L., Crowley, M. \& Quayyum, S. (2007). Understanding the evolution of trade deficits: Trade elasticities of industrialized countries. Economic Perspectives, 31(4).

Duasa, J. (2007). Determinants of Malaysian trade balance: An ARDL bound testing approach. Global Economic Review, 36(1), 89-102.

Edwards, S. (1989). Real exchange rates, devaluation, and adjustment: exchange rate policy in developing countries. MIT press Cambridge, MA.

Eke, I. C., Eke, F. A. \& Obafemi, N. O. (2015). Exchange rate behaviour and trade balances in Nigeria: an empirical investigation. International Journal of Humanities and Social Science, 5(8), 1.

Fariditavana, H. (2016). Exchange rate changes and the trade balance: Is the link symmetric or asymmetric? The University of Wisconsin-Milwaukee.

Ghose, A., Jamal, V. \& Radwan, S. (2005). Tunisia: rural labour and structural transformation. Routledge.

Hunegnaw, F. B. \& Kim, S. (2017). Foreign exchange rate and trade balance dynamics in East African 
countries. The Journal of International Trade \& Economic Development, 26(8), 979-999.

Jedidia, K. Ben, Boujelbène, T. \& Helali, K. (2014). Financial development and economic growth: New evidence from Tunisia. Journal of Policy Modeling, 36(5), 883-898.

Keho, Y. (2015). Foreign Direct Investment, Exports and Economic Growth: Some African Evidence. Journal of Applied Economics \& Business Research, 5(4).

Kyophilavong, P., Shahbaz, M. \& Uddin, G. S. (2013). Does J-curve phenomenon exist in case of Laos? An ARDL approach. Economic Modelling, 35, 833-839.

Lütkepohl, H. (1991). Introduction to multiple time series analysis. Springer Science \& Business Media.

Magee, S. P. (1973). Currency contracts, pass-through, and devaluation. Brookings Papers on Economic Activity, 1973(1), 303-325.

Necșulescu, C. \& Șerbănescu, L. (2013). THE INFLUENCE OF THE FOREIGN TRADE BALANCE ON THE RON/EURO EXCHANGE RATE IN ROMANIA. Young Economists Journal/Revista Tinerilor Economisti, 10(20).

Onakoya, A. B., Johnson, S. B. \& Ajibola, O. J. (2019). Exchange rate and trade balance: The case for J-curve Effect in Nigeria. KIU Journal of Social Sciences, 4(4), 47-63.

Ongan, S., Ozdemir, D. \& Isik, C. (2018). Testing the J-curve hypothesis for the USA: applications of the nonlinear and linear ARDL models. South-Eastern Europe Journal of Economics, 16(1).

Ouattara, B. (2004). Modelling the long run determinants of private investment in Senegal. Credit Research Paper.

Perron, P. (1988). Trends and random walks in macroeconomic time series: Further evidence from a new approach. Journal of Economic Dynamics and Control, 12(2-3), 297-332.

Pesaran, B. \& Pesaran, M. H. (2010). Time series econometrics using Microfit 5.0: A user's manual. Oxford University Press, Inc.

Pesaran, M. H., Shin, Y. \& Smith, R. J. (2001). Bounds testing approaches to the analysis of level relationships. Journal of Applied Econometrics, 16(3), 289-326.

Sam, C. Y., McNown, R. \& Goh, S. K. (2019). An augmented autoregressive distributed lag bounds test for cointegration. Economic Modelling, 80, 130-141.

SHARMA, A., RISHAD, A. \& GUPTA, S. (2019). Measuring the Impact of Oil Prices and Exchange Rate Shocks on Inflation: Evidence from India. Eurasian Journal of Business and Economics, 12(24), 45-64.

Suwanhirunkul, S. \& Masih, M. (2018). Exchange rate and trade balance linkage: sectoral evidence from Thailand based on nonlinear ARDL.

Thomas, R. L. (1997). Modern econometrics: an introduction. Addison-Wesley Longman.

Trinh, P. T. T. (2014). The impact of exchange rate fluctuation on trade balance in the short and long run: the case of Vietnam. Journal of Southeast Asian Economies (JSEAE), 31(3), 432-452.

Tursoy, T. (2019). The interaction between stock prices and interest rates in Turkey: empirical evidence from ARDL bounds test cointegration. Financial Innovation, 5(1), 7.

Yazgan, M. E. \& Ozturk, S. S. (2019). Real Exchange Rates and the Balance of Trade: Does the J-curve Effect Really Hold? Open Economies Review, 30(2), 343-373. 